\title{
Efficacy of Modified Eggs and Chick Muscles on Oxidative Stress of Type-2 Diabetes Mellitus Induced Male Wistar Rats
}

\author{
Kshetrimayum Birla Singh ${ }^{1, *}$ and Satish Kumar Taneja ${ }^{2}$ \\ ${ }^{1}$ Department of Zoology, Pachhunga University College, Mizoram University, Aizawl-796001, India \\ ${ }^{2}$ Department of Zoology, Panjab University, Chandigarh-160014, India
}

\begin{abstract}
A modified poultry egg (Indian Patent Application No. 2264/Del-2005) and chick muscle enriched with optimum minerals, vitamin $E$ and omega-3 fatty acid were developed and its efficacy was studied on oxidative stress of Type-2 diabetes mellitus induced male wistar rats. In this study, two groups of rats were fed on semi-synthetic diet containing $20 \mathrm{mg} \mathrm{Zn/kg} \mathrm{(control,} \mathrm{group-I)} \mathrm{and} 80 \mathrm{mg} \mathrm{Zn/kg} \mathrm{(group-II)} \mathrm{diet} \mathrm{respectively} \mathrm{for} \mathrm{a} \mathrm{period} \mathrm{of} 6$ months. The study revealed that the gain in body weight increased in rats in $\mathrm{Zn}$ concentration dependent manner. The urine examined on weekly basis showed glucosuria in group-II on week 8 and thereafter. The blood lipid profile displayed a significant rise in serum glucose, total lipids, cholesterol, triglycerides, LDL-cholesterol, VLDL-cholesterol whereas HDL-cholesterol showed a reduction in their levels in group-II rats than their control counter parts. They displayed higher lipid peroxidation products and activities of superoxide dismutase, catalase, glutathione-s -transferase, glutathione reductase, glutathione (reduced) and glucose-6-phosphate dehydrogenase were significantly lowered and revealed a higher $\mathrm{Zn}$ concentration and lower $\mathrm{Cu}, \mathrm{Mg}$ and $\mathrm{Mn}$ both in liver and kidney. On day 90, the male rats in group-II after the establishment of type-2 diabetes mellitus, were divided in to two groups- group-IIA and group-IIB. Feeding on these eggs and chick muscles mixed diet in these groups of rats, all the abnormalities were restored and a considerable reduction in lipid peroxidation products and a significant increased in the activities of enzymes per se with reversal of $\mathrm{Zn}, \mathrm{Cu}, \mathrm{Mg}$ and $\mathrm{Mn}$ levels closer to the control group were recorded. The present data suggest that these modified egg and chick muscle are effective in ameliorating the oxidative stress in type-2 diabetes mellitus induced male rats.
\end{abstract}

Keywords: Zinc, modified eggs, chick muscles, oxidative stress, type-Il diabetes mellitus.

\section{INTRODCUTION}

Diabetes mellitus is a global health problem predisposing to markedly increased in cardiovascular mortality and serious morbidity and mortality related to the development of nephropathy, neuropathy and retinopathy [1]. Recently there is increasing evidences in the literature that diabetes is accompanied by imbalances between proxidants and antioxidants factors and this oxidative stress could play a major role in the development of the diabetic complications [2]. The accumulation of lipid peroxide [3] increase in the titre of antibodies against the oxidized LDL have been demonstrated [4] while the activities of the antioxidant enzymes such as superoxide dismutase(SOD), glutathione peroxidise( GPx) may be weakened[5]. It has been seen that oxidative stress has been increasingly implicated in the pathogenesis of diabetes micro and macrovascular diseases [6].

There are reports that excessive $\mathrm{Zn}$ in diet induces obesity, diabetes, dyslipidemia and hypertension in experimental animals [7-9]. Higher concentration of $\mathrm{Zn}$ and lower concentration of $\mathrm{Cu}, \mathrm{Mg}$ and $\mathrm{Mn}$ in the tissues have been reported to link the ionic imbalance of nutritionally important elements to the etiology of

*Address correspondence to this author at the Department of Zoology, Pachhunga University College, Mizoram University, Aizawl-796001, India; Tel: +919863385796; Fax: +9103892315212; E-mail: birla.kshetri@gmail.com diabetes mellitus [10]. This toxic ionic imbalance has been reported to induce oxidative stress in the case of diabetes mellitus.

A number of dietary supplements having antioxidant activity such as vitamin-E [11], omega-3 fatty acids [12] have been reported to reduce the abnormalities associated with type-2 diabetes mellitus. $\mathrm{Cu}$ [13], Mg [14], and Mn [15] have also been shown to be useful in decreasing the severity of the oxidative stress related to this diseases. Therefore non pharmacological intervention is an ideal and attractive way to deal with diabetes mellitus related oxidative stress.

Keeping all these in mind, the characters of macro and micronutrients and their functional aspects, a modified egg (Indian Patent Application No. 2264/Del2005) and chick were developed in which the essential micro and macronutrients have been optimized for individual inflicted with type-2 diabetes mellitus. Since the conjugated form of minerals and vitamins in natural food products are considered more effective than their synthetic forms, the eggs and chick muscles are the most convenient food items which can be modified by manipulation in their feed. The efficacy of these modified eggs and chick muscles on the oxidative stress of type- 2 diabetes mellitus induced male wistar rats is reported in this paper. 


\section{MATERIALS AND METHODS}

The modified eggs and chick muscles used in the experiment were produced by the modification of the constituents of the bird feed at Jaya Health Care Poultry Farm, Panchkula (Haryana), India. Eggs and chicks obtained after feeding on this modified feed were labelled as modified eggs and chick and analyzed for their cholesterol, triglycerides, total lipids, vitamin-E, omega-3 fatty acids and essential minerals ( $\mathrm{Zn}, \mathrm{Cu}$ and $\mathrm{Mg}$ ). Lipids were extracted from homogenates of eggs and chick muscles by the method of Folch et al. [16], using chloroform and methanol $(2: 1)$ as solvent. Total cholesterol [17], triglycerides [18], lipids [19] were estimated from the lipid extract. Proteins [20], carbohydrates [21] were also estimated. Vitamin-E was estimated according to the method of Taylor et al. [22], as detailed by Barker [23]. Omega-3 fatty acids (Linolenic acid) was estimated according to the method of Bindal and Wadhwa [24], using gas liquid chromatography operated at sensitivity of 1000 with column temperature of $150^{\circ} \mathrm{C}$ for 15 minutes and $225^{\circ} \mathrm{C}$ for 12 minutes. $\mathrm{Zn}, \mathrm{Cu}$ and $\mathrm{Mg}$ in the eggs and chick muscles were estimated on atomic absorption spectrophotometer (Electronics Corporation of India Limited, Hyderbad-AAS-4139) using hollow cathode lamps (213.9nm, 324.8nm and $285.2 \mathrm{~nm}$ for $\mathrm{Zn}, \mathrm{Cu}$ and $\mathrm{Mg}$ respectively) Standards for $\mathrm{Zn}, \mathrm{Cu}$, and $\mathrm{Mg}$ were prepared by dilution in triple distilled water deionized water.

\subsection{Experimental Designed}

24 male wistar rats weighing $60-70 \mathrm{~g}$ were procured from Central Animal House of the Panjab University Chandigarh. They were maintained in plastic cages with stainless steel top grill at room temperature (25$28^{\circ} \mathrm{C}$ ) with $14: 10$ hours L: D cycles and $70-80 \% \mathrm{RH}$ as per guidelines of Institutional ethics Committee. They were fed on standard pellet feed for one week to acclimatize. Thereafter the rats were divided in to 2 groups: group-I and II.

\subsection{Preparation of Diet for Rats}

For the present investigations, a semi-synthetic diet rich in fat and refined sucrose was preferred over standard rat pellet diet consisting of natural ingredients to keep consistency of the composition of diet particularly fat, sucrose and micronutrients throughout the experiment and to rule out the possibility of $\mathrm{Zn}$ interactions with fibres and phytates which are known to reduce bioavailability of $\mathrm{Zn}$ by binding it in digestive tract and may take longer time duration feeding to manifest the impact of excessive $\mathrm{Zn}$ in diet [25]. Accordingly isocaloric semi-synthetic diet for the rats was prepared as prescribed by Orgebin-crist et al. [26] (Table 1).

\subsection{Induction of Type-2 Diabetes Mellitus in Group- II Male Rats}

Type-2 diabetes mellitus was induced in group-II male rats by increasing $\mathrm{Zn}$ concentration to $80 \mathrm{mg}$

Table 1: Composition of Basal Diet

\begin{tabular}{|c|c|c|c|}
\hline Diet Components & $g / 100 g$ & *Vitamin Mixture $(\mathrm{mg} / \mathrm{kg})$ & ${ }^{\star \star}$ Mineral Mixture $(\mathrm{g} / \mathrm{kg})$ \\
\hline Casein & 30 & Ascorbic acid -500 & $\mathrm{CaH}_{2} \mathrm{PO}_{4}-25.3$ \\
\hline Agar & 2.0 & Biotin -4 & $\mathrm{CoCl}_{3}-0.04$ \\
\hline Corn oil & 5 & Calcium- D- pentothenate -320 & $\mathrm{CuCl}_{2}-0.10$ \\
\hline Cellulose & 8 & Choline chloride -2500 & $\mathrm{FeSO}_{4} 7 \mathrm{H}_{2} \mathrm{O}-0.60$ \\
\hline Sucrose & 51.0 & Folic acid - 10 & $\mathrm{Mn} \mathrm{SO}_{4 .} 5 \mathrm{H}_{2} \mathrm{O}-0.31$ \\
\hline *Vitamin mixture & 0.50 & Inositol - 1000 & $\mathrm{Mg} \mathrm{SO}_{4} \cdot \mathrm{H}_{2} \mathrm{O}-4.05$ \\
\hline${ }^{* *}$ Mineral mixture & 3.50 & Retinol - 0.31 & $\mathrm{NaF}-0.088$ \\
\hline \multirow[t]{7}{*}{ Total diet } & 100 & Pyridoxine $\mathrm{HCl}-80$ & $\mathrm{KI}-0.004$ \\
\hline & & Riboflavin -120 & $\mathrm{Na}_{2} \mathrm{CO}_{3}-1.15$ \\
\hline & & Ergacalciferol - 0.0031 & $\mathrm{KCL}-3.430$ \\
\hline & & Thiamin $\mathrm{HCl}-200$ & $\mathrm{Zn} \mathrm{SO} 4.7 \mathrm{H}_{2} \mathrm{O}-0.088$ \\
\hline & & $\alpha$-Tocopherol acetate $(E)-60$ & \\
\hline & & Cyanocobalamin - 0.40 & \\
\hline & & Nicotinic acid -300 & \\
\hline
\end{tabular}


$\mathrm{Zn} / \mathrm{kg}$ in semi-synthetic diet rich in fat and refined sugar following the method of Taneja et al. [9]. This method was preferred over stroptozoctocin/alloxan treatment since zinc is a natural component of diet [27], promotes absorption of nutrients [28], induced proliferation of adipocytes [8] and is a component of insulin [29]. Accordingly, isocaloric semi-synthetic basal diet (Table 1) was prepared and divided in to two parts: (i) Control diet (Diet-IC) consisting of basal diet (per se) containing with $20 \mathrm{mg} \mathrm{Zn} / \mathrm{Kg}$ semi-synthetic diet for Group-I (ii) Diabetes inducing diet (Diet-II-ZnDB) consisting of basal diet in which $\mathrm{Zn}$ was increased to $80 \mathrm{mg} \mathrm{Zn/Kg} \mathrm{semi-synthetic} \mathrm{diet} \mathrm{for} \mathrm{Group-II} \mathrm{so} \mathrm{as} \mathrm{to}$ induce diabetes mellitus in this group.

In order to study efficacy of modified eggs and chick muscles, first chick muscles were cut in to small pieces and the quantity of modified eggs and chick muscles to be mixed were measured in a digital electronic balance (Denver, SI-234) to maintain the accuracy of the weights and following diets were prepared: (1) Test diet-A: Four liquid modified eggs weighing $50 \mathrm{~g}$ each mixed in $1 \mathrm{~kg}$ of Diet-II-ZnDB for Group-IIA (2) Test diet$\mathrm{B}: 200 \mathrm{~g}$ of chick muscles mixed in $1 \mathrm{~kg}$ of Diet-II-ZnDB for Group-IIB. The modified egg typically has the following constituents per $50 \mathrm{~g}$ liquid egg: protein, $6.5 \pm$ $0.12 \mathrm{~g}$; carbohydrates, $0.63 \pm 0.003 \mathrm{~g}$; total lipids, 5.84 $\pm 0.043 \mathrm{~g}$; triglycerides, $1.37 \pm 0.008 \mathrm{~g}$; cholesterol, $110.05 \pm 7.15$, linolenic acid, $73.84 \pm 3.75 \mathrm{mg}$, vitamin$\mathrm{E}, 10.35 \pm 0.325 \mathrm{mg}$, zinc, $0.65 \pm 0.002 \mathrm{mg}$; copper, $3.023 \pm 0.045 \mathrm{mg}$; and magnesium, $2.02 \pm 0.015 \mathrm{mg}$ while the composition of chick muscle has total lipids: $1120 \pm 0.924 \mathrm{mg} / 100 \mathrm{~g}$; Triglycerides: $587.7 \pm 1.445$ $\mathrm{mg} / 100 \mathrm{~g}$; Cholesterol: $472.6 \pm 0.621 \mathrm{mg} / 100 \mathrm{~g}$; Phospholipids: $361.8 \pm 1.361 \mathrm{mg} / 100 \mathrm{~g}$; Vitamin-E:1.20 $\pm 0.53 \mathrm{mg} / 100 \mathrm{~g}$; Linolenic acid: $62 \pm 2.56 \mathrm{mg} / 100 \mathrm{~g}$; Zinc- $3.2 \pm 0.016 \mathrm{mg} / 100 \mathrm{~g}$; Copper-5.7 \pm 0.680 $\mathrm{mg} / 100 \mathrm{~g}$; Magnesium: $4.0 \pm 0.788 \mathrm{mg} / 100 \mathrm{~g}$; Carbohydrates- $0.79 \pm 0.036 \mathrm{mg} / 100 \mathrm{~g}$, Proteins: 15.83 $\pm 0.09 \mathrm{~g} / 100 \mathrm{~g}$.

For each diet minerals and water soluble vitamins were ground in sucrose and fat soluble vitamins were dissolved in corn oil. Agar, which serve as a binder was dissolved in $25 \mathrm{ml}$ of triple distilled deionzed water, the contents of each diet were thoroughly mixed in separate containers. The dough so formed was mixed with warm water $\left(60^{\circ} \mathrm{C}\right)$. On cooling to $40^{\circ} \mathrm{C}$, the contents of each diet were thoroughly mixed in separate containers. The dough so formed was put in petridishes and solidified in refrigerator. The solidified diet was cut in to small pieces of $2 \times 2 \times 2 \mathrm{~cm}$ size and stored in the container at the temperature $-4^{0} \mathrm{C}$.

\subsection{Feeding of Rats}

The type-2 diabetes mellitus in Group-II male rats were found to establish on day 90 and was confirmed by hyperglycaemia state like presence of glucose in urine as tested with Benedict's test and rise in blood pressure. All the rats (6 male rats) in Group-I (control) were fed on control diet (Diet-IC), Group-II (18 male rats) on diabetes inducing diet (Diet-II-ZnDB) ad libitium and triple distilled water was made freely available to them for a period of 90 days. On day 90 , 12 male rats from Group-II were separated and subdivided in to two groups each, which were GroupIIA (6 male rats) and Group-IIB (6 male rats). Group-I and II were fed on respective Diet-IC and Diet-II-ZnDB while those of Group-IIA and Group-IIB on Test diet-A and Test diet-B respectively. The experiment was run for all the groups for another 90 days completing 180 days from the start of the experiment. The body weight at the start of dietary treatment and thereafter every week was recorded. Ugobasile blood pressure recording instruments was used for recording the blood pressure and heart rates after anaesthizing the animals by injecting thiopentone sodium ( $25 \mathrm{mg} / \mathrm{kg}$ body weight) intraperitoneally. The urine samples were tested by Benedict's test for the onset of diabetes every week. After the end of dietary treatment of 180 days, the male rats of each group were sacrificed using diethyl ether as anaesthesia.

The blood samples were collected by puncturing the heart. Blood serum was prepared by centrifuging blood at $2500 \mathrm{rpm}$ for 15 minutes. The freshly prepared serum was analyzed for glucose [30], cholesterol [31], triglycerides [32], HDL-cholesterol [33] and total lipids [19]. The LDL and VLDL cholesterol were calculated by using Friedwald's equation [34].

The liver and kidney of four groups of rats were removed for the study of enzyme activities. For this purpose, their homogenates were prepared in $50 \mathrm{mM}$ Tris- HCL buffer ( $\mathrm{pH} \mathrm{7.4)}$ and then centrifuged at 1000 $\mathrm{g}$ for 10 minute at $4^{\circ} \mathrm{C}$ to remove nuclei and debris. Supernatant was again centrifuged at $1000 \mathrm{~g}$ for 30 minute to obtain post mitochondrial supernatant (PMS). The levels of lipid peroxidation (LPO) products were evaluated by the method of Beuge and Aust [35] and glutathione (reduced) (GSH) by the method of Ellman [36] in their PMS fraction. Activities of superoxide dismutase (SOD) [37] catalase (CAT) [38], glutathiones-transferase (Glu-s-T) [39] glutathione reductase (GRD) [40] and glucose- 6-phosphate dehydrogenase (G-6-PD) [41] were estimated in PMS of liver and 
kidney. Protein was evaluated as per of Lowry et al. [20].

$\mathrm{Zn}, \mathrm{Cu} \mathrm{Mg}$ and $\mathrm{Mn}$ were estimated on atomic absorption spectrophotometer (Electronic Corporation of India Limited, Hyderabad-AAS 4139) using hollow cathode lamps $(213 \mathrm{~nm}, 324 \mathrm{~nm}, 285.2 \mathrm{~nm}$ and 279.5 $\mathrm{nm}$ for $\mathrm{Zn}, \mathrm{Cu}, \mathrm{Mg}$ and $\mathrm{Mn}$ respectively). Samples of tissues were digested separately in 3:1 v/v nitric acid and perchloric acid on a sand bath until white ash was formed. The ash was dissolved in $6 \mathrm{ml}$ of $10 \mathrm{mM} \mathrm{HNO}_{3}$ and filtered through ash free filter paper before analysis. Standards of $\mathrm{Zn}, \mathrm{Cu}, \mathrm{Mg}$ and $\mathrm{Mn}$ (sigma) were prepared by dilution in distilled deionized water (TDW). The data were subjected to statistical analysis applying student's t-test.

\section{RESULTS}

The result of the study revealed that during the first 150 days of dietary treatment in group-I \& II, body weight increased with the increased in $\mathrm{Zn}$ concentration in diet. It was then observed that the body weight of the Group-II rats fall than that of the control counterpart during the next 30 days and at day 180 of the experiment. The blood pressure in the rats of group-II was significantly higher than those of the control group. In contrast, the body weight of the groupIIA and IIB rats showed no significant gained and the blood pressure were comparable with respect to control group at the time of the termination of the experiment (Table 2).

The urine of the animals in group-II continued to react positively throughout the experiment. The blood serum revealed significant increase in glucose, cholesterol, triglycerides, LDL and VLDL- cholesterol and lowered HDL-cholesterol than their control counterpart (Table 3 ) indicating that the male rats in group-II were diabetic and hypertensive and continued their displayed throughout the experiment. In contrast,

Table 2: Mean Month Wise Body Weight $(\mathrm{g})$ and Blood Pressure (mm of $\mathrm{Hg}$ ) of Male Rats in Group-I[( Fed on DietIC(Control)], Group-II (Fed on Diet-IIZnDB), Group-IIA( Fed on test diet-A) and Group-IIB ( Fed on test diet-B) During 180 Days of Dietary Treatment

\begin{tabular}{|c|c|c|c|c|c|c|c|c|}
\hline \multirow{2}{*}{$\begin{array}{c}\text { Time } \\
\text { duration } \\
\text { (in } \\
\text { days) }\end{array}$} & \multicolumn{2}{|c|}{ Group-I(Control) } & \multicolumn{2}{|c|}{ Group-II } & \multicolumn{2}{|c|}{ Group-IIA } & \multicolumn{2}{|c|}{ Group-IIB } \\
\hline & Body weight & $\begin{array}{l}\text { Blood } \\
\text { pressure }\end{array}$ & Body weight & $\begin{array}{l}\text { Blood } \\
\text { pressure }\end{array}$ & Body weight & $\begin{array}{l}\text { Blood } \\
\text { pressure }\end{array}$ & Body weight & $\begin{array}{l}\text { Blood } \\
\text { pressure }\end{array}$ \\
\hline 0 & $64.12 \pm 1.20$ & - & $65.10 \pm 0.69$ & - & $65.10 \pm 1.05$ & - & $67.12 \pm 1.45$ & - \\
\hline 30 & $130.24 \pm 1.50$ & $92.86 \pm 1.01$ & $180.00 \pm 1.12^{a}$ & $140.30 \pm 1.15^{a}$ & $179.50 \pm .156^{\mathrm{a}}$ & $140.20 \pm 0.78^{a}$ & $175.34 \pm 1.34^{\mathrm{a}}$ & $145.43 \pm 0.85^{a}$ \\
\hline 60 & $185.21 \pm 0.56$ & $96.50 \pm 0.710$ & $240.22 \pm 1.90^{a}$ & $158.51 \pm 0.64^{a}$ & $236.12 \pm 1.28^{a}$ & $150.13 \pm 0.89^{a}$ & $235.45 \pm 1.78^{\mathrm{a}}$ & $155.24 \pm 0.95^{a}$ \\
\hline 90 & $225.50 \pm 1.70$ & $98.62 \pm 1.12$ & $262.23 \pm 1.02^{\mathrm{a}}$ & $170.12 \pm 2.10^{a}$ & $260.34 \pm 1.34^{\mathrm{a}}$ & 158. $10 \pm 1.24^{\mathrm{a}}$ & $264.22 \pm 1.34^{\mathrm{a}}$ & $165.14 \pm 2.41^{a}$ \\
\hline 120 & $245.82 \pm 1.25$ & $96.10 \pm 2.10$ & $270.10 \pm 0.82^{a}$ & $187.20 \pm 1.30^{a}$ & ${ }^{\Omega} 265.86 \pm 1.14^{a}$ & ${ }^{\Omega} 170.01 \pm 1.20^{a}$ & ${ }^{\Omega} 266.12 \pm 1.35^{a}$ & ${ }^{\Omega} 176.0 \pm 1.64^{a}$ \\
\hline 150 & $255.10 \pm 1.70$ & $104.24 \pm 2.31$ & $275.15 \pm 1.34^{a}$ & $205.12 \pm 1.59^{a}$ & ${ }^{\Omega} 290.86 \pm 4.26^{a}$ & $\Omega_{174.10} \pm 0.96^{a}$ & ${ }^{\Omega} 289.12 \pm 1.67^{a}$ & $\Omega_{172.21} \pm 1.24^{a}$ \\
\hline 180 & $260.20 \pm 2.20$ & $105.20 \pm 2.12$ & $250.10 \pm 2.02^{\mathrm{a}}$ & $220.15 \pm 2.12^{\mathrm{a}}$ & ${ }^{\Omega} 295.41 \pm 3.15^{\mathrm{a}}$ & ${ }^{\Omega} 165.22 \pm 0.85^{\mathrm{a}}$ & ${ }^{\Omega} 296.12 \pm 2.01^{a}$ & $\Omega_{170.71} \pm 2.15^{a}$ \\
\hline
\end{tabular}

Values are mean \pm SE of 6 observations each; ${ }^{\Omega}$ Animals shifted to test diet-A and B; $P$ values: ${ }^{a}<0.001$ (Values of Group-II, Group-IIA and Group-IIB were compared with Group-I).

Table 3: Blood Profile of Male Rats of Group-I[( Fed on Diet-IC(Control)], Group-II (Fed on Diet-II-ZnDB), Group-IIA( Fed on test diet-A) and Group-IIB ( Fed on test diet-B) after 180 Days of Dietary Treatment

\begin{tabular}{|c|c|c|c|c|}
\hline Parameters & Group-I(Control) & Group-II & ${ }^{\Psi}$ Group-IIA & ${ }^{\Psi}$ Group-IIB \\
\hline \hline Glucose $^{*}$ & $75.04 \pm 1.24$ & $180.12 \pm 0.55^{\mathrm{a}}$ & $78.12 \pm 1.12^{\mathrm{b}}$ & $80.10 \pm 0.86^{\mathrm{a}}$ \\
\hline Total Lipids* $^{*}$ & $185.40 \pm 1.24$ & $272.18 \pm 0.85^{\mathrm{a}}$ & $195.34 \pm 0.46^{\mathrm{a}}$ & $200.22 \pm 0.98^{\mathrm{a}}$ \\
\hline Cholesterol* $^{*}$ & $55.12 \pm 1.52$ & $96.0 \pm 0.78^{\mathrm{a}}$ & $60.24 \pm 0.54^{\mathrm{a}}$ & $62.24 \pm 0.52^{\mathrm{a}}$ \\
\hline Triglycerides $^{*}$ & $62.64 \pm 1.12$ & $110.50 \pm 1.15^{\mathrm{a}}$ & $65.14 \pm 0.26^{\mathrm{b}}$ & $70.02 \pm 0.65^{\mathrm{a}}$ \\
\hline HDL-cholesterol $^{\mathrm{a}}$ & $16.35 \pm 0.62$ & $10.34 \pm 0.25^{\mathrm{a}}$ & $14.12 \pm 0.65^{\mathrm{b}}$ & $14.0 \pm 0.24^{\mathrm{b}}$ \\
\hline VLDL-Cholesterol $^{*}$ & $12.52 \pm 0.96$ & $22.10 \pm 0.87^{\mathrm{a}}$ & $13.00 \pm 0.96^{\mathrm{N}}$ & $14.00 \pm 0.90^{\mathrm{b}}$ \\
\hline LDL-Cholesterol $^{*}$ & $33.77 \pm 0.60$ & $63.56 \pm 0.54^{\mathrm{a}}$ & $32.98 \pm 0.24^{\mathrm{N}}$ & $34.00 \pm 0.45^{\mathrm{N}}$ \\
\hline
\end{tabular}

Units: ${ }^{*} \mathrm{mg} / \mathrm{dl}$; Values are mean $\pm \mathrm{SE}$ of 6 observations each; ${ }^{\psi}$ Estimations made after 90 days of dietary egg and chick muscle treatment; $P$ values: ${ }^{a}<0.001,{ }^{b}<$ $0.01,{ }^{N}<$ Non significant values (Values of Group-II, Group-IIA and Group-IIB were compared with Group-I). 
Table 4: Mean Lipid Peroxidation and Enzymes Activities in Liver of Male Rats in Group-I[( Fed on Diet-IC(Control)], Group-II (Fed on Diet-II-ZnDB), Group-IIA( Fed on Test diet-A) and Group-IIB ( Fed on Test diet-B) after 180 Days of Dietary Treatment

\begin{tabular}{|c|c|c|c|c|}
\hline Parameters & Group-I(Control) & Group-II & ${ }^{\Psi}$ Group-IIA & ${ }^{\Psi}$ Group-IIB \\
\hline Lipid Peroxidation* & $0.70 \pm 0.04$ & $1.65 \pm 0.18^{a}$ & $0.71 \pm 0.06^{\mathrm{N}}$ & $0.65 \pm 0.08^{c}$ \\
\hline Superoxide dismutase ${ }^{* *}$ & $10.24 \pm 0.25$ & $6.47 \pm 0.28^{\mathrm{a}}$ & $10.12 \pm 0.05^{\mathrm{N}}$ & $9.82 \pm 0.07^{\mathrm{N}}$ \\
\hline Catalase $^{@}$ & $45.42 \pm 2.34$ & $30.22 \pm 1.95^{\mathrm{a}}$ & $45.32 \pm 1.10^{N}$ & $44.23 \pm 1.20^{N}$ \\
\hline Glutathione-s- transferase ${ }^{\#}$ & $0.652 \pm 0.04$ & $0.542 \pm 0.03^{a}$ & $0.645 \pm 0.02^{c}$ & $0.559 \pm 0.05^{b}$ \\
\hline Glutathione( reduce) $)^{\$}$ & $8.02 \pm 0.10$ & $5.22 \pm 1.10^{\mathrm{a}}$ & $8.56 \pm 0.24^{\mathrm{N}}$ & $7.90 \pm 0.86^{\mathrm{N}}$ \\
\hline Glutathione reductase $^{\&}$ & $9.14 \pm 1.76$ & $5.42 \pm 1.60^{\mathrm{a}}$ & $9.07 \pm 0.27^{\mathrm{N}}$ & $9.10 \pm 0.85^{\mathrm{N}}$ \\
\hline $\begin{array}{l}\text { Glucose-6-phosphate } \\
\text { dehydrogenase }\end{array}$ & $10.10 \pm 1.08$ & $4.28 \pm 1.10^{\mathrm{a}}$ & $9.62 \pm 0.65^{c}$ & $8.78 \pm 0.45^{b}$ \\
\hline
\end{tabular}

Values are mean \pm SE of 6 observations each; ${ }^{\psi}$ Estimations made after 90 days of dietary egg and chick muscle treatment; Units: ${ }^{*}$ nmol MDA produced/hr/mg protein, ${ }^{* *}$ : unit/mg protein, ${ }^{\circledR}: \mu \mathrm{mol} \mathrm{H}_{2} \mathrm{O}_{2}$ decomposed/min/mg protein), \# $\mu$ mol of CDNB-GSH conjugate formed/min/mg protein, ${ }^{\$}: \mathrm{nmol}$ GSH/mg/protein; ${ }^{\star}: \mathrm{nmol}$ NADPH oxidized/min/mg protein); ${ }^{\#: ~}$ nmol NADPH formed/min/mg protein; $P$ values: ${ }^{\mathrm{a}}<0.001,{ }^{\mathrm{b}}<0.01,{ }^{\mathrm{c}}<0.05,{ }^{\mathrm{N}}<\mathrm{Non}$ significant values.(Values of Group-II, Group-IIA and Group-IIB were compared with Group-I).

the reactivity of urine samples to Benedict's solution started declining in the rats of group-IIA and IIB and it reacted negatively at the end of the experiment. Their blood serum glucose, triglycerides, LDL-C, VLDL-C and HDL-c were comparable to those of the control group-I (Table 3).

The lipid peroxidation products were found to be significantly higher in liver and kidney of group-II comparable to those control group showing weak antioxidant defense system in this group of rats. Their higher levels in group-II male rats coincided with the enzymes of antioxidant defense system i.e. SOD, CAT, Glu-s-T, GRD, GSH and Glu-6-PD whose activities were evaluated significantly less in this group. On the contrary, all the activities of the enzymes mention per se in the rats of group-IIA and IIB fed on test diet A and $B$ were comparable to those of their control counterparts suggesting an improved of antioxidant defense system as revealed by the reduction of lipid peroxidation products in them (Tables 4,5 ).

The trace metal status in the liver and kidney of group-II male rats shows higher $\mathrm{Zn}$ concentration and lowered $\mathrm{Cu}, \mathrm{Mg}$ and $\mathrm{Mn}$ that the control group-I. Their concentrations were restored in group-IIA and IIB closer to the control rats (Table 6).

\section{DISCUSSION}

The results revealed that supplementation of greater amount of $\mathrm{Zn}$ equal to $80 \mathrm{mg} / \mathrm{kg}$ and not exceeding $100 \mathrm{mg} / \mathrm{kg}$ diet to the male rats of Group-II resulted significance gain in body weight, significantly higher blood pressure and their urine reacted positively with Benedict's test suggesting the onset of obesity,

Table 5: Mean Lipid Peroxidation and Enzymes Activities in Kidney of Male Rats in Group-I[( Fed on Diet-IC(Control)], Group-II (Fed on Diet-II-ZnDB), Group-IIA( Fed on Test diet-A) and Group-IIB ( Fed on Test diet-B) after 180 Days of Dietary Treatment

\begin{tabular}{|c|c|c|c|c|}
\hline Parameters & Group-I(Control) & Group-II & ${ }^{\Psi}$ Group-IIA & ${ }^{\Psi}$ Group-IIB \\
\hline Lipid Peroxidation* & $0.65 \pm 0.03$ & $1.24 \pm 0.96^{\mathrm{a}}$ & $0.67 \pm 0.09^{N}$ & $0.60 \pm 0.07^{c}$ \\
\hline Superoxide dismutase ${ }^{* *}$ & $9.64 \pm 1.00$ & $5.40 \pm 1.14^{\mathrm{a}}$ & $10.06 \pm 0.97^{c}$ & 9. $45 \pm 0.87^{N}$ \\
\hline Catalase $^{@}$ & $40.24 \pm 1.20$ & $25.23 \pm 2.00^{a}$ & $40.65 \pm 1.54^{\mathrm{N}}$ & $40.00 \pm 0.96^{\mathrm{N}}$ \\
\hline Glutathione-s- transferase $\mathrm{e}^{\#}$ & $0.612 \pm 0.04$ & $0.425 \pm 0.08^{\mathrm{a}}$ & $0.605 \pm 0.08^{\mathrm{N}}$ & $0.578 \pm 0.05^{c}$ \\
\hline Glutathione( reduce) $)^{\$}$ & $9.25 \pm 0.12$ & $5.25 \pm 1.42^{\mathrm{a}}$ & $9.00 \pm 0.67^{N}$ & $8.57 \pm 0.50^{c}$ \\
\hline Glutathione reductase ${ }^{\&}$ & $8.05 \pm 1.20$ & $6.20 \pm 0.978^{a}$ & $8.10 \pm 0.75^{\mathrm{N}}$ & $7.90 \pm 1.10^{\mathrm{N}}$ \\
\hline Glucose-6-phosphate dehydrogenase & $9.4 \pm 1.28$ & $4.56 \pm 1.87^{\mathrm{a}}$ & $8.90 \pm 0.10^{\mathrm{N}}$ & $8.55 \pm 0.56^{c}$ \\
\hline
\end{tabular}

Values are mean \pm SE of 6 observations each; ${ }^{\psi}$ Estimations made after 90 days of dietary egg and chick muscle treatment;. Units: *: nmol MDA produced/hr/mg protein, ${ }^{* *}$ : unit $/ \mathrm{mg}$ protein, $@$ : $\mu \mathrm{mol} \mathrm{H}_{2} \mathrm{O}_{2}$ decomposed $/ \mathrm{min} / \mathrm{mg}$ protein, ${ }^{*}$ : $\mathrm{mol}$ of CDNB-GSH conjugate formed $/ \mathrm{min} / \mathrm{mg} \mathrm{protein}$, ${ }^{\$}: \mathrm{nmol} \mathrm{GSH} / \mathrm{mg} / \mathrm{protein} ;{ }^{*}: \mathrm{nmol}$ NADPH oxidized/min/mg protein; ${ }^{\#:}$ nmol NADPH formed/min/mg protein, $P$ values: ${ }^{a}<0.001,{ }^{c}<0.05,{ }^{N}<$ Non significant values.(Values of Group-II, Group-IIA and Group-IIB were compared with Group-I). 
Table 6: Mean $\mathrm{Zn}, \mathrm{Cu}, \mathrm{Mg}$ and Mn Concentrations in Liver and Kidney of Male Rats in Group-I[( Fed on DietIC(Control)], Group-II (Fed on Diet-II-ZnDB), Group-IIA( Fed on Test diet-A) and Group-IIB ( Fed on Test dietB) after 180 Days of Dietary Treatment

\begin{tabular}{|c|c|c|c|c|}
\hline Parameters & Group-I(Control) & Group-II & ${ }^{\Psi}$ Group-IIA & ${ }^{\Psi}$ Group-IIB \\
\hline \hline Liver $\mathrm{Zn}^{*}$ & $32.14 \pm 0.841$ & $50.12 \pm 2.10^{\mathrm{a}}$ & $35.45 \pm 1.10^{\mathrm{a}}$ & $37.52 \pm 1.25^{\mathrm{a}}$ \\
\hline Liver $\mathrm{Cu}^{*}$ & $50.12 \pm 1.25$ & $34.14 \pm 0.77^{\mathrm{a}}$ & $51.24 \pm 1.45^{\mathrm{N}}$ & $48.67 \pm 1.78^{\mathrm{N}}$ \\
\hline Liver Mg $^{*}$ & $55.22 \pm 2.10$ & $36.42 \pm 1.15^{\mathrm{a}}$ & $54.14 \pm 1.24^{\mathrm{N}}$ & $52.50 \pm 1.45^{\mathrm{b}}$ \\
\hline Liver $\mathrm{Mn}^{*}$ & $35.14 \pm 2.50$ & $25.40 \pm 1.85^{\mathrm{a}}$ & $36.24 \pm 0.95^{\mathrm{N}}$ & $35.12 \pm 0.75^{\mathrm{N}}$ \\
\hline Kidney $\mathrm{Zn}^{*}$ & $30.42 \pm 1.14$ & $38.24 \pm 1.20^{\mathrm{a}}$ & $28.20 \pm 0.34^{\mathrm{b}}$ & $27.24 \pm 0.78^{\mathrm{a}}$ \\
\hline Kidney $\mathrm{Cu}^{*}$ & $45.10 \pm 1.20$ & $32.52 \pm 2.46^{\mathrm{a}}$ & $46.10 \pm 1.02^{\mathrm{N}}$ & $45.12 \pm 1.34^{\mathrm{N}}$ \\
\hline Kidney $\mathrm{Mg}^{*}$ & $54.42 \pm 1.65$ & $40.10 \pm 1.25^{\mathrm{a}}$ & $53.24 \pm 0.95^{\mathrm{N}}$ & $52.24 \pm 0.54^{\mathrm{b}}$ \\
\hline Kdiney $\mathrm{Mn}^{*}$ & $40.12 \pm 1.12$ & $25.42 \pm 1.87^{\mathrm{a}}$ & $42.12 \pm 0.76^{\mathrm{b}}$ & $40.10 \pm 0.56^{\mathrm{N}}$ \\
\hline
\end{tabular}

Values are mean \pm SE of 6 observations each; ${ }^{\psi}$ Estimations made after 90 days of dietary egg and chick muscle treatment; Units: ${ }^{*}: \mu g / g$ of tissue weight; $P$ values: ${ }^{a}<0.001,{ }^{b}<0.01,{ }^{N}<$ Non significant values. (Values of Group-II, Group-IIA and Group-IIB were compared with Group-I).

hypertension and glucosuria in them. The blood profile also revealed higher total lipids, triglycerides, cholesterol, LDL-c, VLDL-C and glucose level than those of the control group indicating that the rats in group-II fed on Diet-II-ZnDB were typically diabetic with the complications of hypertension and dyslipidemia and continued to display throughout the experiment. Such disorder in diabetes mellitus have been reported previously $[8,9,42]$ and the contribution of $\mathrm{Zn}$ in induction of obesity, diabetes mellitus, dyslipidemia and hypertension in rats feeding on increased amount of $\mathrm{Zn}$ have been discussed.

The reduction in the blood pressure in the group IIA and group - IIB male rats fed on test diet A and B may be due to the availability of adequate levels of vitamins and minerals in the diet. In animals, certain elements such as copper restricted diets have been shown to induce a variety of physiological and pathological cardiovascular abnormalities that are similar to presented by patients with coronary heart diseases [43]. Moreover, it lend support to the observations per se that the insulin resistance in these group of rats were ameliorated and glucose level returned close the base line as revealed by the Benedict test.

The blood profile of the group - IIA and IIB male rats revealed a reduction in the serum cholesterol, total lipids, triglycerides, LDL and VLDL- c, glucose and significant increase in the serum HDL-c than those of control group-I. These changes in the blood of rats fed on modified eggs and chick muscles mixed test diet- $A$ and $B$ appear to be imposed a positive effect when fed in diet and can be attributed to the vitamins, trace minerals present in the modified eggs and chick muscles mixed diet. It was reported that $\mathrm{Cu}, \mathrm{Mg}$ and $\mathrm{Cr}$ were involved in normal carbohydrate and lipid metabolism and insufficient of these dietary elements induced anemia, pancreatic atrophy, heart hypertrophy, glucose intolerance and elevated blood lipid [44-46]. Moreover, these changes in the blood of male rats of group-IIA and IIB showed an improvement in functioning of the liver and other tissues. The increased glycogenesis and lipogenesis in the liver has a direct bearing on the glucose, cholesterol, LDL-c, VLDL-c, triglycerides and $\mathrm{HDL}-\mathrm{C}$ of the blood which are insulin dependent.

The lipid peroxidation products in the liver and kidney of group - II diabetic male rats increased significantly than those of the control group-l. The persistence of hyperglycemia has been reported as a cause of increased production of oxygen free radicals through glucose auto-oxidation and non-enzymatic glycations. Advanced glycation or glycosylations end products (AGEs) are the products of glycation and glycoxidation which are increased at an accelerated rate in the diabetes mellitus [47]. Increased lipid peroxidation in diabetes mellitus is due to an altered intracellular ratio between free radicals and antioxidant system [48]. And the imbalance between free radical production and antioxidant capacity leads to oxidative stress which in turn is associated with the development of cardiovascular disease [49]. Since the group-II male rats were diabetic, as expected the lipid peroxidation products were recorded higher than those of the control group-I rats indicating that these rats were under constant oxidative stress. There are several mechanisms in which organisms defend itself against oxidative stress. Among them, there are small 
molecular antioxidants such as GSH and antioxidant scavenging enzymes such as cellular $\mathrm{Cu}, \mathrm{Zn}-\mathrm{SOD}$, CAT, GPx and Glu-s-T [49-51]. The production of the lipid peroxidation products depends on the activities of the antioxidant enzymes such as SOD, CAT, Glu-s-T, GRD, GSH and Glu-6-PD which registered a significant reduction in liver and kidney of group-II male rats. These observations are in conformity with that of Kinalski et al. [52], Muhammad et al. [53], Ugochukkwu et al. [54] and Sailaja et al. [55] who had reported that patients with type-II diabetes mellitus have significant defect of antioxidant protection, which may cause vulnerability to such oxidative damage and development of the diabetic complications.

The decrease in the lipid peroxidation products in group -IIA and group - IIB male rats even lower than the control level is attributed to the essential minerals present in the modified eggs and chick muscles which led to the restoration of the minerals status in their tissues close to the control rats. The assessment of the mineral status estimated in the group-II male rats revealed an ionic balance wherein an elevated concentration of the $\mathrm{Zn}$ in both liver and kidney and that of the $\mathrm{Cu}, \mathrm{Mg}$ and $\mathrm{Mn}$ were lowered while their concentrations were restored, even more than the control group-I in some cases in group-IIA and groupIIB male rats both in the liver and kidney. As a consequence of this, the activities of all the enzymes investigated were increased, even more, in group-IIA and group-IIB rats than control. Metallic ions being an integral component of these enzymes per se, the deficiency of some of the metals such as $\mathrm{Cu}, \mathrm{Zn}, \mathrm{Mg}$ and $\mathrm{Mn}$ have been reported to result in the reduction in enzymes activities of antioxidant defense system and increase in peroxidation products in diabetic rats [56, 57]. It was also reported by several studies that underlie the alteration of antioxidant micronutrient status in subjects with type- I and type- II diabetes mellitus [58-61] and may influence antioxidant enzymes activity through disturbances in micronutrient status [59]. SOD requires manganese, copper and zinc, GPX needs selenium and catalase contains haem as cofactor [62, 63]. In view of these, it has been suggested that the supplementation of trace elements such as $\mathrm{Se}, \mathrm{Cu}, \mathrm{Zn}$ and $\mathrm{Mn}$, the essential component of the enzymes structures, may be useful in preventing the development of the diabetic complications [64]. The antioxidant system is a coordinated system in which the deficiencies in any one of the component will impact the efficiency of others. A deficiency in these micronutrients leads to the oxidative stress, which leaves body tissue open to the damaging effects of oxidative intermediates seen in many diseases.

\section{CONCLUSION}

Thus, the restoration trends noticed in antioxidant enzyme activity level on feeding modified eggs and chick muscle mixed test $\operatorname{diet} A$ and $B$ in the rats of group -IIA and group -IIB male rats appear to be due to sparing action of optimized concentration of dietary minerals present in the modified eggs and chick muscles bestowed on their metalloenzymes complex as these minerals are the essential components of these antioxidants enzymes. The activities of the enzymes investigated were increased even more in these group of rats than that of the control group-I indicating thereby complete restoration of antioxidant defense system to the level of control group which in turn led to reduction of lipid peroxidation. This is evident from the data wherein inclusion of modified eggs and chick muscle in the group-IIA and IIB respectively resulted in the restoration of mineral concentration to the baseline. This resulted in the reduction of oxidative stress and other complications associated with type-2 diabetes mellitus. Since our indigenous antioxidant defense are not completely effective, it seems reasonable to propose that dietary micronutrients are particularly important in diminishing the cumulative effects of oxidative damage and the modified eggs and chick muscles serve this function. Therefore, a combination of micro and macronutrients in appropriate amounts in modified eggs and chick muscle is more potent in providing lasting effect than their presence singly and thus reduce the severity of the oxidative stress in Type-2 diabetes mellitus as is evident from the data per se.

\section{ACKNOWLEDGEMENTS}

The financial aid provided to Department of Zoology, Panjab University Chandigarh under UGCSAP, Phase-III by University Grants Commission (UGC), New Delhi and the Research Fellowship to K. Birla Singh by UGC, New Delhi are gratefully acknowledge.

\section{REFERENCES}

[1] Zimmet PZ, McCarty DJ, Courten MP. The global epidemiology of non insulin dependent diabetes mellitus and the metabolic syndrome. J Diabe Compl 1997; 11: 60-8. http://dx.doi.org/10.1016/S1056-8727(96)00090-6

[2] Somogyi A, Pusxtai $\mathrm{P}$, Prech J, et al. The hypothetical connection of diabetes mellitus and free radical reactions with atherosclerosis. Orv Hetil 1994; 135: 1815-8. 
[3] Noberasco C, Odetti P, Boemi D, et al. Malondialdehyde (MDA) level in diabetes subjects. Relationship with blood glucose and glycosylated haemoglobin. Biomed and Pharma 1991; 45: 193-6.

http://dx.doi.org/10.1016/0753-3322(91)90107-5

[4] Bellomom G, Maggi E, Poli M, et al. Autoantibodies against oxidatively modified low density lipoproptens in NIDDM. Diabetes 1995; 44: 60-6. http://dx.doi.org/10.2337/diab.44.1.60

[5] Kawamura N, Okawara T, Suzuki K, et al. Increased glycated $\mathrm{Cu}, \mathrm{Zn}$ - superoxide dismutase levels in erythrocytes of patients with IDDM. J Clin Endocrin Metab 1992; 746: 13524.

http://dx.doi.org/10.1210/jc.74.6.1352

[6] Mustafa A, David EL. Diabetes, oxidative stress and physical exercise. J Sport Sc Med 2002; 1: 1-14.

[7] Pomp D, Oberbauer A M, Murray JD. Growth and body composition of OMT-la- OGH transgenic male mice with differing periodsof transgenic activation. J Anim Sci 1992; 70(1): 198-1.

http://dx.doi.org/10.1007/BF01979918

[8] Pomp D, Oberbauer AM, Murray JD. Development of obesity following inactivation of a growth transgene in mice. Transgenic Res 1996; 5: 13-3.

[9] Taneja SK, Mandal R, Girhotra S. Long term excessive Zn supplementation promotes metabolic Syndrome-X in wistar rats fed sucrose and fat rich semi-synthetic diet. Ind J Exp Bio 2006; 44: 705-8. http://dx.doi.org/10.1007/s12011-007-8035-1

[10] Taneja SK, Mandal R. Assessment of minerals in obesity related diseases in the Chandigarh (India) population. Biol Trace Elem Res 2008; 121: 106-2.

[11] Ohtsuka A Ohtani T, Horiguchi H, Kojima H, Hayashi K. Vitamin $\mathrm{E}$ reduces glucocorticoid-induced growth inhibition and lipid peroxidation in rats. J Nutr Sci Vitaminol 1998; 44: 237-7.

http://dx.doi.org/10.3177/jnsv.44.237

[12] Goodfellow J, Bellamy MF, Ramsey MW, Jones CJH, Lewis MJ. Dietary supplementations of marine omega-3 fatty acids improve systemic large artery endothelial function in subjects with hypercholesterolemia. J Am Coll Cardiol 2000; 35(2): 265-0.

http://dx.doi.org/10.1016/S0735-1097(99)00548-3

[13] Umerson J. Serum cholesterol and HDL-cholesterol levels as accociated with copper and zinc intake in physically active and sedentary elderly men and women. Adv Exp Med Biol 1989; 258: 171-1.

[14] Balon TW, Gu JJ, Tokuyama Y, Jasman AP and Nadler JJ. Magenesium supplementation reduces development of diabetes in a rat model of spontaneous NIDDM. Am J Physiol 1995; 269: 745-2.

[15] Everson GJ, Shrader RE. Abnormal glucose tolerance in manganese deficient guinea pigs. J Nutr 1968; 94: 89-4.

[16] Folch JLM, Less M, Solane- Staneley GH. A simple method for the isolation and purification of total lipids from animal tissues. J Biol Chem 1957; 226: 497-9.

[17] Chiamori N, Henry RJ. Study of the ferric chloride method for the determination of total cholesterol and cholesterol ester. Am J Clin Pathol 1995; 31(4): 305-9.

[18] Gottfried SP, Rosenberg B. Improved manual spectrophotometric procedure for the determination of the serum triglycerides. Clin Chem 1973; 19: 1077-8.

[19] Frings CS, Dunn RT. A calorimetric method for determination of total serum lipids based on sulphophosphovanillin reaction. Am J Clin Path 1970; 53: 89-4.

[20] Lowry OH, Rosebrough NJ, Farr, AL, Randall RJ. Protein measurement with the folin phenol reagent. J Bio Chem 1951; 193: 265-5.
[21] Heatly NG. The distribution of glycogen in the regions of amphibian gastrula with method for micro determination of glycogen. Biochem J 1935; 29: 68-2.

[22] Taylor SL, Lamden MP, Tappel AL. Sensitive fluorometric method for tissue tocopherol analysis. Lipids 1976; 11: 5308. http://dx.doi.org/10.1007/BF02532898

[23] Barker D, Fitzpatrick MP, Dierenfield ES. Nutrient composition of selected whole invertebrates. Zoo Biol 1998; 17: $123-9$.

http://dx.doi.org/10.1002/(SICI)1098 2361(1998)17:2<123::AID-ZOO7>3.0.CO;2-B

[24] Bindal MP, Wadhwa BK. Detection of adulteration in ghee with vegetable oils using GLC based on a marker fatty acid. Indian J Dairy Sci 1997; 50: 129-3.

[25] Oberleas D, Herland BF. Phytate content of foods: effect on dietary zinc bioavailability. J Ame Diet Ass 1981; 79: 433- 6.

[26] Orgebin-crist MC, Freeman M, Barney GH. Sperm formation in Zn-deficient rats. Annals Bio-chem Biophys 1971; 11: 5478. http://dx.doi.org/10.1051/rnd:19710403

[27] National Research Council. Recommended dietary allowance. $10^{\text {th }}$ ed. National Academy Press, Washington, D.C. 1989.

[28] Koo SI, Turk DE. Effect of Zn deficiency on intestinal transport of triglycerides in rats. J Nutr 1997; 107: 909-9.

[29] Faure P, Roussel A, Coudray C, Richard MJ, Halimi J, Favier S. Zinc and insulin sensitivity. Bio Trace Elem Res 1992; 32: 305-0. http://dx.doi.org/10.1007/BF02784615

[30] Trinder P. Determination of glucose in blood using glucose oxidase with alternative glucose acceptor. Annual Clin Biochem 1969; 6: 24-25.

[31] Roeschlau P, Bernt E, Gurber WA. Enzymatic determination of total cholesterol in serum. J Clin Chem Clin Bioch 1974; 1974: 232-6.

[32] McGowan MW, Artiss JD, Stranberg DR, Zak BA. Peroxide coupled method for colorimetric determination of serum triglycerides. Clin Chem 1983; 29: 438-2.

[33] Burstein M, Schonick HR, Morfin R. Rapid method for the isolation of lipoproteins from human serum by precipitation with polyanions. J Lipids Res 1970; 11: 583-5.

[34] Friedewald WT, Levy RI, Fredrickson RS. Estimation of concentration of LDL-cholesterol in plasma without use of preparative ultracentrifuge. Clin Chem 1972; 18(6): 499-2.

[35] Beuge JA, Aust SD. Microsomal lipid peroxidation. Method Enzyme 1978; 52: 302-0.

http://dx.doi.org/10.1016/S0076-6879(78)52032-6

[36] Ellman GL. Tissue sulphydryl Groups. Arch Bioch Bioph 1959; 82: 70-7.

http://dx.doi.org/10.1016/0003-9861(59)90090-6

[37] Nishikimi M, Rao NA, Yagi K. The occurrence of superoxide anion in the reaction of reduced phenazine methosulphate and molecular oxygen. Bioch Biophy Res Comm 1972; 46(2): 849-9. http://dx.doi.org/10.1016/S0006-291X(72)80218-3

[38] Aebi AE. "Catalase," In: Bergnmeyer HV, Ed., Methods of Enzymatic Analysis, $3^{\text {rd }}$ ed. Aca-demic Press, New York 1983; Vol. 3: pp. 273-86.

[39] Habig W, Pabst, MJ, Jackboy WB. Glutathione-s-transfrase. The first enzymatic step in mercapturic acid formation. J Biol Chem 1974; 249: 7130-9.

[40] Horn HD. "Glutathione Reductase," In: Berg-Meyer HV, Ed. Methods of Enzymatic Analysis, Academic Press, New York 1971; pp. 875-1. 
[41] Lohr GW, Waller HD. Glucose-6-phosphate dehydrogenase, In: Bergmeyer HV, Ed. Methods of enzymatic analysis; Academic Press, New York 1963; p. 744.

[42] Chen MD, Lin PY, Cheng V, Lin WH. Zinc supplementation aggravates body fat accumulation in genetically obese mice and dietary obese mice. Biol Trace Elem Res 1996; 52: 1252.

http://dx.doi.org/10.1007/BF02789454

[43] Allen, KGD, Klevay LM. Copper on antioxidant nutrient for cardiovascular health. Curr Opin Lipidol 1994; 5: 22-8. http://dx.doi.org/10.1097/00041433-199402000-00005

[44] Davis, GK, Mertz W. Copper trace elements in human and animal nutrition. In Murtz W. Eds. Trace Orlando. Academic Press 1: 301-6.

[45] Corica F, Allegra A, Benedetto AD, Giacobbe MS, Romano G, Cucinotta D. Effect of oral magnesium supplementation on lipid concentration in patients with non-insulin dependent diabetes mellitus. Magnesium Res 1994; 7: 43-7.

[46] Anderson RA. Chromium metabolism and its role in disease progress in man. Clin Physio Biochem 1986; 4: 31-1.

[47] Shell DR, Lapolla A, Odetti P, Fogarty J, Monnier VM. Pentosidine formation in skin correlates with severity of complications in individuals with long standing IDDM. Diabetes 1992; 41: 675-6.

[48] Altomare F, Vendemiale G, Chicco D, Procacci V, Cielli F. Increased lipid peroxidation in type-2 poorly control diabetic patients. Diabetes Metab 1992; 18(4): 264-1.

[49] Penckofer S, Schwertz D, Florczak K. Oxidative stress and cardiovascular disease in type-2 diabetes: the role of antioxidants and pro-oxidants. J Cardiovasc Nurs 2002; 16(2): 68-5. http://dx.doi.org/10.1097/00005082-200201000-00007

[50] Kasapoglu M, Ozben T. Alteration of antioxidant enzymes and oxidative stress makers in aging. Exp Gerontol 36: 2090 .

http://dx.doi.org/10.1016/S0531-5565(00)00198-4

[51] Touyz RM. Oxidative stress and vascular damage in hypertensions. Curr Hypertens Rep 2000; 2: 98-5. http://dx.doi.org/10.1007/s11906-000-0066-3

[52] Kinalski M, Seldziewski A, Telejko B, et al, Lipid peroxidation and scavenging enzymes activities in streptozoctocin induced diabetes. Acta Diabetol 2000; 37: 179-3. http://dx.doi.org/10.1007/s005920070002

[53] Muhammad A, Mudassir AK, Abdus SK. Naturally occurring antioxidant vitamin levels in patients with type -II diabetes mellitus. J Ayub Med Coll Abbottabad 2004; 15(1): 1-6.
[54] Ugochukkwu NH, Babady NE, Cobourne M, et al. The effect of Gongronema latifolium extracts on serum lipid profile and oxidative stress in hepatocytes of diabetic rats. J Biosci 2003; 28: 1-5.

http://dx.doi.org/10.1007/BF02970124

[55] Sailaja YR, Baskar R, Saralakumari D. The antioxidant status during malnutrition of reticulocytes to erythrocytes in type-2 diabetics. Free Radic Biol Med 2003; 35: 133-9. http://dx.doi.org/10.1016/S0891-5849(03)00071-6

[56] Anderson RA, Roussel, AM, Zouari N, Mahjoub S, Matheau JM, Kerkeni A. Potential antioxidant effect of zinc and chromium supplementation in people with diabetes mellitus. J Am Coll Nutr 2001; 20: 212-5. http://dx.doi.org/10.1080/07315724.2001.10719034

[57] Sindhu RK, Koo JR, Robert CK, Vazioori ND. Dysregulation of hepatic superoxide dismutase, catalase and glutathione peroxidase in diabetes: response to insulin and antioxidant therapies. Clin Exp Hyperten 2004; 26: 45-3. http://dx.doi.org/10.1081/CEH-120027330

[58] Mooradian AD, Failla M, Hoogwerf B, Maryniuk M, WylieRoset J. Selected vitamins and minerals in diabetes. Diabetes Care 1994; 5: 464-8.

[59] Strain JJ. Disturbance of the micronutrients and antioxidant status in diabetes. Proc Nutr Soc 1991; 50: 591-4. http://dx.doi.org/10.1079/PNS19910073

[60] Ruiz C, Alegria A, Barbera R, Farre R Lagarda MJ. Selenium, zinc and copper in plasma of patients with type-I diabetes mellitus in different metabolic control states. J Trace Elem Biol 1998; 12: 91-5. http://dx.doi.org/10.1016/S0946-672X(98)80031-X

[61] Walter RM, Uriu- Hare JY, Olin KL, Oster MH, Anawalt BD, Critchfield JW, Keen CL. Copper, zinc, manganese, and magnesium complications of diabetes mellitus. Diabetes Care 1991; 14: 1051-6. http://dx.doi.org/10.2337/diacare.14.11.1050

[62] Paynter DI. The role of dietary copper, manganese, selenium and vitamin- $E$ in lipid peroxidation in tissue of rats. Biol Trace Elem Res1980; 2: 121-5. http://dx.doi.org/10.1007/BF02798591

[63] Olin KL, Walter RM, Keen CL. Copper deficiency affects selenoglutathione peroxidase and selenodeiodinase activities and antioxidant defences in weanling rats. Am J Clin Nutr 1994; 59: 654-8.

[64] Rahbani-Nobar, ME, Rahimi-Pour A, Rahbani-Nobar M, AdiBeig F, Mirhashemi SM. Total antioxidant capacity, superoxide dismutase and glutathione peroxidase in diabetic patients. Med J Islamic Acad Sci 1999; 12: 2012-4.

Received on 05-09-2013

Accepted on 29-09-2013

Published on 31-10-2013

DOI: http://dx.doi.org/10.6000/1929-5634.2013.02.03.3

(c) 2013 Singh and Taneja; Licensee Lifescience Global.

This is an open access article licensed under the terms of the Creative Commons Attribution Non-Commercial License (http://creativecommons.org/licenses/by-nc/3.0/) which permits unrestricted, non-commercial use, distribution and reproduction in any medium, provided the work is properly cited. 